The University of Maine

DigitalCommons@UMaine

1992

Identification of the subspecies of Oreochromis niloticus (Pisces:

Cichlidae) using restriction endonuclease analysis of

mitochondrial DNA

Seifu Seyoum

Irv Kornfield

Follow this and additional works at: https://digitalcommons.library.umaine.edu/sms_facpub

Part of the Oceanography and Atmospheric Sciences and Meteorology Commons

This Article is brought to you for free and open access by DigitalCommons@UMaine. It has been accepted for inclusion in Marine Sciences Faculty Scholarship by an authorized administrator of DigitalCommons@UMaine. For more information, please contact um.library.technical.services@maine.edu. 


\title{
Identification of the subspecies of Oreochromis niloticus (Pisces: Cichlidae) using restriction endonuclease analysis of mitochondrial DNA
}

\author{
Seifu Seyoum ${ }^{\mathrm{a} .1}$ and Irv Kornfield ${ }^{\mathrm{b} .2}$ \\ a Department of Biology, University of Waterloo, Waterloo, Ont. N2L 3GI, Canada \\ ${ }^{b}$ Department of Zoology, University of Maine, Orono, ME 04469, USA
}

(Accepted 26 May 1991)

\section{ABSTRACT}

Seyoum, S. and Kornfield, I., 1992. Identification of the subspecies of Oreochromis niloticus (Pisces: Cichlidae) using restriction endonuclease analysis of mitochondrial DNA. Aquaculture, 102: 2942.

Restriction endonuclease analysis of mitochondrial DNA (mtDNA) was used to characterize differentiation among the seven described subspecies of Oreochromis niloticus from East Africa and Egypt. Mitochondrial DNAs of 14 populations were examined with 42 restriction endonucleases. Two subspecies of Oreochromis spilurus were also examined. Approximately $8 \%$ of the mitochondrial genome of $O$. niloticus ( $17070 \pm 40$ base pairs) was assayed; $29(70 \%)$ of the 42 restriction enzymes that were examined displayed restriction phenotypes that varied among the samples analyzed.

Several endonucleases produced restriction phenotypes which were diagnostic for the described subspecies of $O$. niloticus, though a few samples did not agree with the conventional taxonomy of the group. Extensive differentiation of some populations suggests that additional taxonomic recognition is warranted. Because all subspecies of Oreochromis niloticus could be distinguished by their unique restriction enzyme profiles, analysis of mtDNA can be used to identify the crigin of cultured stocks. This study provides the first molecular key for the objective identification of this taxon.

\section{INTRODUCTION}

The cichlid fish Oreochromis niloticus (Linnaeus) is one of the most important taxa in global aquaculture today (FAO, 1980). The species occurs naturally in East and West Africa, though its distribution is not continuous. It is probably the most widespread and the most abundant of all the tilapiine species having been extensively introduced into many areas of the world (Welcomme, 1981). These introduced populations of $O$. niloticus have been founded from a variety of both natural and cultured sources (Trewavas,

\footnotetext{
'Present address: Department of Zoology, Brigham Young University, Provo, UT 84602, USA.

${ }^{2}$ To whom correspondence should be addressed.
} 
1983). The identification of taxa and of cultured stocks is central to aquaculture and effective fishery management of tilapias.

Oreochromis niloticus has been subjected to detailed morphological study and analysis. The most recent systematic treatment (Trewavas, 1983) divided the taxon into seven subspecies: $O$. niloticus baringoensis Trewavas, $O$. $n$. cancellatus (Nichols), O. n. eduardianus (Boulenger), $\boldsymbol{O}$. $n$. filoa Trewavas, $O$. n. niloticus (Linnaeus), $O$. $n$. sugutae Trewavas, and $O$. $n$. vulcani (Trewavas). This classification is based on osteological features and composite differences in meristic and morphometric characters. However, none of these characters, either singly or in combination, can be used to unambiguously identify individual fish: all characters overlap among subspecies. Additionally, this situation can be exacerbated by potential environmental influences on meristic traits, morphometric characters and population parameters (Dentry and Lindsey, 1978; Ryman et al., 1984; Beacham and Murry, 1986). If some attributes on which these taxa have been characterized are indeed plastic, their usefulness for stock identification in aquaculture may be limited.

Protein electrophoresis has been used extensively to delineate species and differentiation among populations of fishes (e.g. Shaklee, 1983; Utter, 1987). In tilapias, some studies using allozymes have very successfully discriminated among species (Kornfield et al., 1979; McAndrew and Majumdar, 1983, 1984). However, many species of cichlids are exceedingly similar when assayed by this technique, possessing identical alleles at most loci (Sage and Selander, 1975; Kornfield, 1984; McKaye et al., 1984; Sage et al., 1984; Kornfield 1991). This is particularly true for taxa of very recent origin. In such cases, protein electrophoresis is not sufficiently sensitive to reveal discriminatory genetic characteristics. Extensive protein electrophoresis was conducted by Seyoum $(1989,1990)$ for eleven population samples representing five subspecies of $O$. niloticus (O. n. baringoensis, $O$. $n$. cancellatus, $O$. $n$. filoa, $O$. n. sugutae, and $O$. $n$. vulcani). Though four of the 32 resolved loci were polymorphic, no diagnostic alleles were present and allele frequencies could not be used to discriminate among subspecies. Thus, an alternative method for objective identification of tilapias was pursued.

The technique of restriction endonuclease analysis of mitochondrial DNA (mtDNA) has been successfully exploited for stock identification and population analysis in fishes (Ferris and Berg, 1987; Gyllensten and Wilson, 1987; Kornfield and Bogdanowicz, 1987). Because of its small size, taxonomic homology, absence of recombination and ease of isolation, the mtDNA genome is an excellent system for population analysis (Wilson et al., 1985; Avise et al., 1987; Moritz et al., 1987). Strict maternal inheritance (Lansman et al., 1981 ) insures that each lineage accumulates its own mutations in the mtDNA genome. Further, the apparent rapid rate of mtDNA evolution relative to nuclear DNA (Brown, 1983) has provided sensitivity sufficient to resolve acute taxonomic problems in ichthyology (Avise et al., 1986). Restriction enzyme 
analysis of mtDNA permits quantification of variation at the nucleotide level and provides a large number of characters for comparative purposes. Here we exploit restriction enzyme analysis of mtDNA to define the subspecies of $O$. niloticus.

\section{MATERIALS AND METHODS}

Twelve populations of Oreochromis niloticus and two populations of the related congener $O$. spilurus were examined (Table 1 ). A few of the samples were taken from waters that are interconnected to some degree. Three samples from the Gallo Lakes in the Ethiopian Rift (Lakes Abijata, Langano and Zewai) are interconnected by intermittent streams; these three localities are lumped together in analyses. There are potential interconnections between the Blue Nile and the White Nile, but distances between populations (e.g. in Lake Albert and Lake Tana) are very large and intervening habitats are very diverse.

Specimens were dissected in the field and tissues were placed in cryotubes and transported to the laboratory on dry ice. Tissue samples were stored up to 7 months at $-70^{\circ} \mathrm{C}$ prior to analysis.

Mitochondrial DNA was extracted from ovarian tissue using cesium chloride/ethidium bromide gradient ultracentrifugation (Lansman et al., 1981 ). Aliquots of purified mtDNA were digested (Maniatias et al., 1982) for $5 \mathrm{~h}$

\section{TABLE 1}

Source and samples of Oreochromis niloticus and Oreochromis spilurus. Nomenclature according to Trewavas (1983); acronym according to the results in this study. $N$ indicates sample size

\begin{tabular}{|c|c|c|c|c|c|}
\hline Taxon & Source $^{\mathrm{a}}$ & Latitude & Longitude & $N$ & Acronym \\
\hline o. n. baringoensis & L. Baringo, Kenya & $0^{\circ} 38^{\prime} \mathrm{N}$ & $36^{\circ} 05^{\prime} \mathrm{E}$ & 3 & $\mathbf{B B}$ \\
\hline O. n. cancellatus & L. Abijata, ${ }^{\text {b }}$ Ethiopia & $7^{\circ} 38^{\prime} \mathrm{N}$ & $38^{\circ} 27^{\prime} \mathrm{E}$ & 9 & $\mathrm{CC}$ \\
\hline O. n. cancellatus & L. Awassa, Ethiopia & $7^{\circ} 03^{\prime} \mathrm{N}$ & $38^{\circ} 27^{\prime} \mathrm{E}$ & 4 & $\mathrm{CC}$ \\
\hline O. n. cancellatus & L. Akaki, Ethiopia & $8^{\circ} 40^{\prime} \mathrm{N}$ & $38^{\circ} 35^{\prime} \mathrm{E}$ & 3 & FF \\
\hline O. n. cancellatus & L. Chamo, Ethiopia & $5^{\circ} 50^{\prime} \mathrm{N}$ & $37^{\circ} 40^{\prime} \mathrm{E}$ & 3 & $\mathrm{CC}$ \\
\hline O. n. cancellatus & L. Tana, Ethiopia & $12^{\circ} 00^{\prime} \mathrm{N}$ & $37^{\circ} 20^{\prime} \mathrm{E}$ & 3 & CT \\
\hline O. n. eduardianus & L. Victoria, Kenya & $1^{\circ} 00^{\prime} \mathrm{S}$ & $33^{\circ} 00^{\prime} \mathrm{E}$ & 3 & EV \\
\hline o. n. filoa & R. Awash (Metehara), Ethiopiac & $8^{\circ} 53^{\prime} \mathrm{N}$ & $39^{\circ} 53^{\prime} \mathrm{E}$ & 3 & $\mathbf{F F}$ \\
\hline o. n. filoa & L. Beseka, Ethiopia & $8^{\circ} 52^{\prime} \mathrm{N}$ & $39^{\circ} 52^{\prime} \mathrm{E}$ & 3 & $\mathrm{CC}$ \\
\hline O. n. niloticus & L. Manzilah, Egypt & $31^{\circ} 08^{\prime} \mathrm{N}$ & $32^{\circ} 00^{\prime} \mathrm{E}$ & 3 & NM \\
\hline O. n. sugutae & R. Suguta (Lopetakinyanga), Kenya & $1^{\circ} 00^{\prime} \mathrm{N}$ & $36^{\circ} 15^{\prime} \mathrm{E}$ & 3 & SS \\
\hline O. n. vulcani & L. Turkana (Loyengalini), Kenya & $3^{\circ} 30^{\prime} \mathrm{N}$ & $36^{\circ} 05^{\prime} \mathrm{E}$ & 3 & VT \\
\hline O. s. spilurus & R. Tana, Kenya & $1^{\circ} 03^{\prime} \mathrm{N}$ & $37^{\circ} 05^{\prime} \mathrm{E}$ & 5 & ST \\
\hline$O$. s. niger & L. Turkana, Kenya & $3^{\circ} 30^{\prime} \mathbf{N}$ & $36^{\circ} 05^{\prime} \mathrm{E}$ & 3 & ST \\
\hline
\end{tabular}

${ }^{a} L=$ Lake (Amaharic, Hyke); $R=$ River (Wonze).

'Includes samples from interconnected Lake Langano (latitude $7^{\circ} 38^{\prime} \mathrm{N}$, longitude $38^{\circ} 35^{\prime} \mathrm{E}$ ) and Lake Zewai $\left(8^{\circ} 00^{\prime} \mathrm{N}, 38^{\circ} 50^{\prime} \mathrm{E}\right)$.

'Names in parentheses are local names of places where samples were collected. 
using 42 restriction endonucleases: 27 six-base enzymes ( $A p a I, B a m \mathrm{HI}, B c l$, $B g l$, BglII, BstEII, ClaI, DraI, EcoRI, EcoRV, HindIII, HpaI, KpnI, MluI, NarI, Ncol, Ndel, NruI, PstI, PvuII, Sall, SmaI, SphI, SstII, XbaI, Xhol, XmnI ), three 5.3-base enzymes ( $A v a \mathrm{I}, \mathrm{HincII}, S t y \mathrm{I})$, one 5-base enzyme (MboII), three 4.6-base enzymes (AvaII, EcoRII, $N c i I$ ) and eight four-base enzymes (HaeIII, HinfI, HhaI, Mbol, MspI, RsaI, ThaI, TaqI ). The resulting cleavage fragments were endlabelled with ${ }^{32} \mathrm{P}$ dNTPs by the method of Drouin (1980). Fragments were separated according to size by standard agarose gel (1-2\%) electrophoresis using 1000-base-pair (bp)-size standards (Bethesda Research Laboratories, Bethesda, MD) on each gel. Restriction fragment patterns were visualized by autoradiography (Kodak XO-Mat AR film and Dupont Cronex Lightning Plus screens); exposure was typically $2 \mathrm{~h}$ at room temperature. Restriction fragment sizes were determined from autoradiographs using a polynomial regression equation derived from the fragment mobilities of the standard.

For each population, a minimum of three individuals was examined. A single letter was assigned to each cleavage phenotype observed for each enzyme; a 29-letter sequence constitutes the composite phenotype or clonal type of a specimen. Thirteen enzymes that did not cleave the mtDNA, or gave identical multibanded patterns, were not included in the composite phenotype.

\section{RESULTS}

Of the 42 restriction enzymes examined, ten did not cleave the mtDNA genome (BamHI, ClaI, EcoRI, KpnI, MluI, NruI, Sall, Smal, SstII, and XhoI ). Three additional enzymes ( $B g I$, EcoRV, and NarI) had identical multibanded phenotypes among all subspecies and $O$. spilurus. The mtDNA genome was estimated to be $17020 \pm 40$ base pairs in length; based on the number of fragments visualized, we estimate that approximately $8 \%$ of the mitochondrial genome was assayed.

A total of 97 phenotypes was observed for the 29 polymorphic enzymes (Table 2). The fragment sizes of these phenotypes are provided in the Appendix. MtDNA restriction fragment patterns produced with $A p a$ I are illustrated in Fig. 1. No intrapopulation polymorphisms were observed for any enzyme; from each population, all individuals examined had identical phenotypes.

Several unique and discriminatory cleavage phenotypes were found for the subspecies, with the highest degree of resolution observed using four-base restriction enzymes. A dichotomous key to the described subspecies of $O$. niloticus using diagnostic mtDNA restriction enzyme phenotypes is given in Table 3. The key was constructed employing six enzymes and can be used to objectively identify single individuals in the absence of locality information.

Of the seven populations morphologically assigned to $O$. niloticus cancellatus (Trewavas, 1983), five (Lakes Abijata, Awassa, Chamo, Langano and 


\section{ABLE 2}

Mitochondrial DNA cleavage phenotypes of Oreochromis niloticus subspecies and Oreochromis spilurus. Sample size was three individuals for each population. Abbı eviations of samples as in Table 1

\begin{tabular}{|c|c|c|c|c|c|c|c|c|c|}
\hline \multirow{2}{*}{$\begin{array}{l}\text { Restriction } \\
\text { enzyme }\end{array}$} & \multicolumn{9}{|c|}{ Samples } \\
\hline & BB & $\mathrm{CC}$ & $\mathrm{CT}$ & EV & FF & NM & SS & VT & $\mathbf{S T}^{\mathrm{a}}$ \\
\hline Apal & I & $G$ & $\mathbf{H}$ & $\mathbf{M}$ & $G$ & $\mathbf{H}$ & $\mathbf{H}$ & H & $E$ \\
\hline Aval & $C$ & A & B & B & $A$ & B & B & $\mathbf{B}$ & $G$ \\
\hline Avall & $\mathbf{M}$ & $A$ & $\mathbf{E}$ & D & $A$ & D & D & D & C \\
\hline$B c / I$ & $A$ & A & $\mathbf{A}$ & A & B & $A$ & A & A & A \\
\hline Bg/II & A & B & A & A & B & A & A & A & $\mathrm{E}$ \\
\hline BstEII & D & A & A & B & $A$ & B & B & B & B \\
\hline Dral & $\overline{\mathbf{B}}$ & A & $\mathrm{B}$ & $\mathrm{H}$ & A & B & $\mathbf{B}$ & $\mathbf{B}$ & A \\
\hline EcoRII & $\mathrm{C}$ & A & $\mathrm{A}$ & C & $A$ & A & B & B & $E$ \\
\hline HaellI & A & $\mathbf{H}$ & $\mathrm{A}$ & $\mathbf{B}$ & $\mathrm{H}$ & C & $\mathrm{A}$ & A & $\bar{D}$ \\
\hline Hhal & $E$ & B & A & $\mathrm{E}$ & $\mathrm{D}$ & A & E & $\mathbf{E}$ & $\bar{G}$ \\
\hline HincII & B & A & B & B & $A$ & B & B & $\bar{B}$ & $\mathrm{C}$ \\
\hline HindIII & A & A & D & D & A & D & D & D & $A$ \\
\hline Hinfl & C & B & A & A & B & A & D & A & $\mathrm{E}$ \\
\hline Hpal & $\mathbf{A}$ & B & A & A & B & A & $\mathrm{A}$ & $\mathrm{A}$ & $\mathrm{A}$ \\
\hline Mbol & $\mathbf{F}$ & D & $\mathrm{F}$ & $\mathrm{F}$ & $\bar{A}$ & $\mathrm{~F}$ & $B$ & $\Gamma$ & $\mathrm{E}$ \\
\hline Mboll & A & A & $\mathrm{C}$ & A & $\mathbf{E}$ & A & $A$ & B & $\bar{D}$ \\
\hline MspI & B & $\mathrm{E}$ & B & $\mathbf{J}$ & $\mathbf{E}$ & B & B & B & $\bar{D}$ \\
\hline Ncil & B & A & B & B & A & $x$ & B & B & $\mathbf{E}$ \\
\hline Ncol & $A$ & A & $\mathbf{A}$ & $\mathrm{A}$ & $A$ & A & A & A & $\mathrm{C}$ \\
\hline NdeI & $\mathrm{A}$ & A & A & $\mathrm{A}$ & A & $A$ & A & A & $\mathrm{C}$ \\
\hline Psll & B & A & A & B & $A$ & A & $\mathbf{A}$ & $A$ & A \\
\hline Pvull & $\mathbf{A}$ & $\mathrm{A}$ & $\mathrm{E}$ & A & $A$ & A & $A$ & A & A \\
\hline Rsal & B & D & $E$ & $G$ & D & G & A & $\mathbf{F}$ & C \\
\hline SphI & B & A & $A$ & A & A & $A$ & $A$ & A & $\mathrm{E}$ \\
\hline$S t y)$ & $\mathrm{D}$ & $A$ & A & A & A & $A$ & A & A & $\overline{\mathbf{E}}$ \\
\hline Taql & $\mathrm{C}$ & B & $A$ & $\mathrm{D}$ & B & $\mathrm{C}$ & $\mathrm{C}$ & C & $\mathrm{F}$ \\
\hline Thal & A & $\mathrm{B}$ & $\mathrm{A}$ & $A$ & B & A & $\mathrm{A}$ & $A$ & B \\
\hline$X b a I$ & A & $\mathrm{A}$ & $A$ & A & $\bar{A}$ & A & $A$ & A & $\mathbf{B}$ \\
\hline$X m n I$ & $\mathrm{C}$ & A & A & C & A & $\mathrm{C}$ & C & C & A \\
\hline $\begin{array}{l}\text { Number of } \\
\text { populations }\end{array}$ & & & & & & & & & \\
\hline sampled & 1 & 6 & 1 & 1 & 2 & 1 & 1 & 1 & 2 \\
\hline
\end{tabular}

ancludes both subspecies of $O$. spilurus (O. s. niger and $O$. s. spilurus).

Zewai) showed identical mtDNA composite phenotypes. However, the sample of $O$. $n$. cancellatus from Lake Tana exhibited different phenotypes for 19 of the 29 polymorphic enzymes and the sample of $O$. $n$. cancellatus from Lake Akaki showed mtDNA composite phenotypes different from its assigned subspecies. In addition, the samples from Lake Beseka were not similar to $O . n$. filoa, the taxon to which they had been assigned (see Discussion).

Pairwise comparison of the number of differences in mtDNA composite 


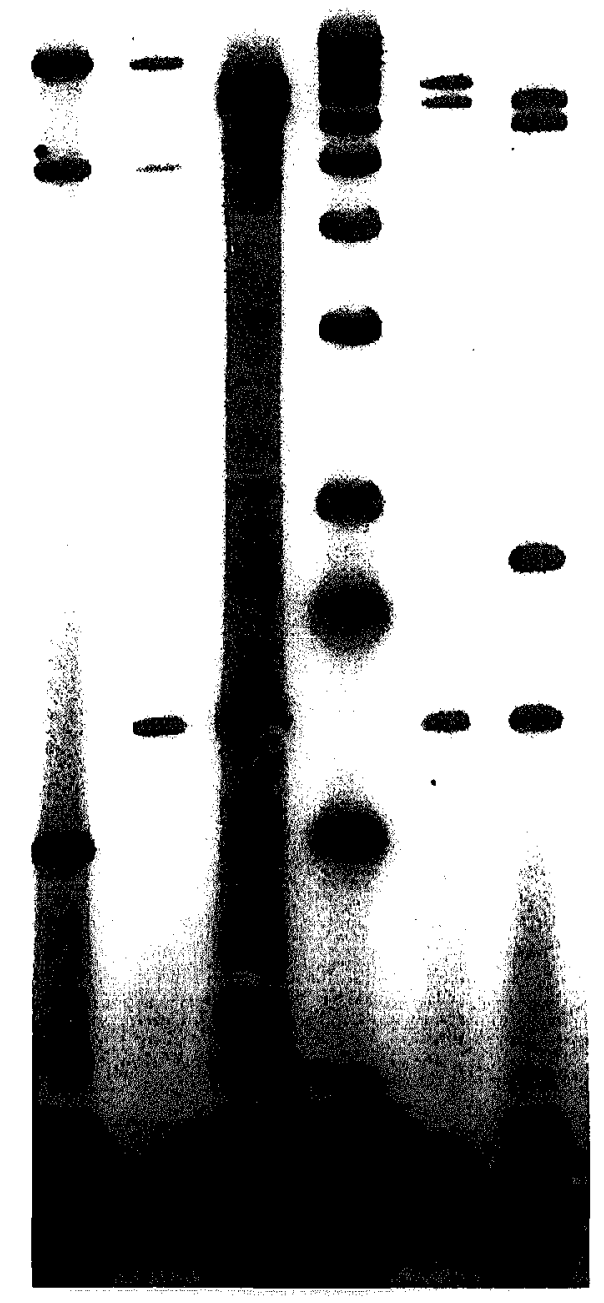

Fig. 1. Mitochondrial DNA restriction fragment patterns produced with A $/$ laI. Samples (left to right ), Oreochromis niloticus cancellatus, $O$. spilurus spilurus, $O$. $n$. vulcani, I kb molecular weight standard, $O . n$. sugutae, and $O . n$. baringoensis.

phenotypes between samples of the subspecies of $O$. niloticus and between $O$. spilurus are provided in Table 4. Each phenotypic difference represents (minimally) one mutation step. Of particular note are differences exhibited by the samples from Lake Tana that had been assigned to 0 . $n$. cancellatus (Trewavas, 1983). The two subspecies of $O$. spilurus showed identical phenotypes for all 29 poiymorphic enzymes. Formal treatment of the evolutionary relationships among the subspecies will be presented elsewhere. 


\section{TABLE 3}

Dichotomous key to the described subspecies of Oreochromis niloticus from East Africa and Egypt, based on mitochondrial DNA restriction enzyme phenotypes. Many other keys can be constructed from the composite phenotypes (see Table 2)
1. A. Dral "H"
O. n. eduardianus
B. All other phenotypes
O. n. sugutae
2. A. Hinf :D":
B. All other phenotypes .
O. n. vulcani
3. A. Rsal "F"
B. All other phenotypes
o. n. filoa
4. A. Bcll "B"
B. All other phenotypes
5. A. Aval "A" or "E"
B. All other phenotypes
6. A. Aval "A"
B. Aval "E"
cancellatus
.. n. cancellatus
7. A. Ncil "X"
(Lake Tana population)
B. Hinfl "C"
o. n. niloticus
o. n. baringoensis

\section{TABLE 4}

Number of mitochondrial DNA cleavage phenotype differences between the subspecies of Oreochromis niloticus and Oreochromis spilurus (ST). Total number of polymorphic enzymes was 29

\begin{tabular}{llrrrrrrrr}
\hline & & CC & CT & EV & FF & NM & SS & VT & ST \\
\hline O. n. baringoensis & & 21 & 17 & 13 & 24 & 14 & 12 & 12 & 25 \\
O. n. cancellatus & (CC) & - & 19 & 21 & 4 & 19 & 20 & 21 & 22 \\
O. n. canccllatus & (CT) & - & - & 14 & 20 & 9 & 11 & 8 & 23 \\
O.n. eduardianus & (EV) & - & - & - & 23 & 9 & 10 & 9 & 25 \\
O.n. filoa & (FF) & - & - & - & - & 21 & 22 & 22 & 23 \\
O.n.niloticus & (NM) & - & - & - & - & - & 7 & 6 & 24 \\
O.n. sugutae & (SS) & - & - & - & - & - & - & 4 & 24 \\
O.n. vulcani & (VT) & - & - & - & - & - & - & - & 24 \\
\hline
\end{tabular}

\section{DISCUSSION}

In previous studies, protein electrophoresis could not be used to discriminate among five of the subspecies of Oreochromis niloticus (Seyoum, 1989, 1990). Indeed, the tilapiine fishes are morphologically very similar and no earlier work has successfully identified any taxonomic group below the species level with allozyme analysis. However, using restriction endonuclease analysis of mtDNA, we were able to unambiguously distinguish all the subspecies.

Several keys to the subspecies of $O$. niloticus can be drawn from diagnostic restriction enzyme patterns (Table 2, Appendix). One dichotomous key is 
illustrated in Table 3. Alternatively, the subspecies can be discriminated by cleavage phenotypes for only three restriction endonucleases: $A p a I, B c l I$ and RsaI (Table 2). Thus, for introduced or cultured tilapias, assuming that stocks have remained genetically isolated (i.e., have experienced no hybridization since they were obtained from the wild), mtDNA analysis can be exploited to indicate their origin.

One important factor in the effective exploitation of mtDNA polymorphism for the purpose of stock or subspecies identification is adjustment for intrapopulation variation. Variation of $\mathrm{mtDNA}$ within populations has been found in a number of fishes, e.g., rainbow trout, Oncorhynchus mykiss (Palva and Palva, 1987), Atlantic herring, Clupea harengus (Kornfield and Bogdanowicz, 1987), Great Lakes walleye, Stizostedion vitreum (Billington and Hebert, 1988) and southern African hakes, Merluccius spp. (Becker et al., 1988 ). However, no variation was observed within any of the populations we sampled. Indeed, the sample sizes in this study (Table 1) may not be sufficient to expose all clones that may occur within a population. However, the complete absence of differentiation among the lakes inhabited by $O$. $n$. cancellatus strongly suggests that variation within populations is very limited. On the other hand, a great deal of interspecific polymorphism was observed as differences among the subspecies. Our ability to perceive these differences among populations strongly suggests that we could also have been able to recognize variation within populations had it been present.

Relationships within the $O$. niloticus subspecies complex derived from our analysis of mtDNA basically support the morphological classification of the group; each subspecies can be recognized by four or more unique restriction enzyme patterns (Table 4). However, there are three inconsistencies between the mtDNA findings and expectations from the current taxonomy of the group. The first case involves the position of the specimens from Lake Tana. Fish from Lake Tana, morphologically assigned to $O$. $n$. cancellatus by Trewavas (1983) differed from other population samples of that subspecies for 19 of 29 informative endonucleases (Table 4). The population in Lake Tana is not $O$. $n$. cancellatus, but represents an additional, previously unrecognized taxon. This fish has apparently remained static in morphology while its mtDNA diversified; the magnitude of distinctiveness may warrant taxonomic recognition.

A second exception to the conventional taxonomy involves identification of the fish collected from Lake Beseka (Metehara). This small Ethiopian iake possesses a number of hot streams around its periphery. Cichlids from Lake Beseka were thought by Trewavas (1983) to be allied to $O$. $n$. filoa since she believed that this taxon was adapted to high temperatures. However, analysis of fish from this location showed mtDNA restriction phenotypes identical to those of specimens assigned by Trewavas to $O$. $n$. cancellatus. Our identification of these fish as $O$. $n$. cancellatus is consistent with the idea that $O$. n. filoa 
is naturally limited in distribution to the Awash system; Lake Beseka has no connection with the River Awash.

The final inconsistency between morphology and mtDNA data concerns the cichlid of Lake Akaki, an intentional impoundment in the River Awash system associated with hydrological development in the region. The lake is cold, shallow and muddy. Trewavas (1983) examined five specimens of $O$. niloticus from Lake Akaki, assigned them to $O$. $n$. cancellatus, but noted that they had meristics similar to $O$. $n$. filoa. The low number of dorsal fin elements in some Akaki specimens suggested to her that these fish may have been stocked from an Awash River hot spring since populations in high-temperature areas could display reduced fin elements. However, the fish we collected from Lake Akaki did not show mtDNA phenotypes for $O$. $n$. cancellatus, but instead had phenotypes characteristic of $O$. $n$. filoa from hot springs in the Awash near Metehara. Though her taxonomic allocation was incorrect, Trewavas (1973) had anticipated this finding by identifying meristic inconsistencies of these fish.

The use of restriction endonuclease analysis of mitochondrial DNA has allowed us to establish a molecular key to distinguish among the subspecies of $O$. niloticus. With a single individual, identification using morphology is virtually impossible in the absence of locality information. Given the global scale of aquaculture involving $\boldsymbol{O}$. niloticus, we suggest that additional coordinated molecular studies of wild and cultured stocks should be undertaken. Such an effort would be useful for preservation of gene pools and unambiguous identification of cultured or wild stocks. We hope that our findings will assist in stock identification programs and aquaculture research.

\section{AC $:$ NOWLEDGEMENTS}

We would like to acknowledge the invaluable assistance of C.H. Fernando, A. Tekeste, G. Hartman, P. Kat, G. Teferra, P. Moran, D. McElroy and J. Everett. Ethelwynn Trewavas provided inspiration and insight during the entire study. J. Moring and C.H. Fernando kindly commented on this manuscript. We are particularly indebted to an anonymous reviewer who greatly improved presentation of our findings.

For assisting with the collection of samples we acknowledge help of $T$. Wudnehe, Charles Nugugu, Manager of the Sagana Fish Culture Station in Kenya and the Officers of the Fishery Department of Kenya at Lakes Baringo, Turkana, and Victoria. Brenden McAndrew kindly provided specimens of $O$. n. niloticus for our use.

Our research was supported by the Canadian International Development Agency, the University of Waterloo and the Addis Ababa University Freshwater Fisheries and Limnology project (CIDA-UW-AAU-FFLP) and by NSF BSR grants 84-16131 and 85-77040 (to I.K.). 


\section{REFERENCES}

Avise, J.C., Helfman, G.S., Saunders, N.C. and Hales, L.S., 1986. Mitochondrial DNA differentiation in North Atlantic eels: Population genetic consequences of an unusual life history pattern. Proc. Natl. Acad. Sci. U.S.A., 83: 4350-4354.

Avise, J.C., Arnold, J., Ball, R.M., Bermingham, E., Lamb, T., Neigel, J.E., Reeb, C.A. and Saunders, N.C., 1987. Intraspecific phylogeography: the mitochondrial DNA bridge between population genetics and systematics. Annu. Rev. Ecol. Syst., 18: 489-522.

Beacham, T.D. and Murry, C.B., 1986. The effect of spawning time and incubation temperature on meristic variation in chum salmon (Oncorhynchus keta). Can. J. Zool., 64: 45-48.

Becker, I.I., Grant, W.S., Kirby, R. and Robb, F.T., 1988. Evolutionary divergence between sympatric species of southern African hakes, Merluccius capensis and $M$. paradoxus: II. Restriction enzyme analysis of mitochondrial DNA. Heredity, 61: 21-30.

Billington, N. and Hebert, P.D.N., 1988. Mitochondrial DNA variation in Great Lakes walleye (Stizostedion vitreum) populations. Can. J. Fish. Aquat. Sci., 45: 643-654.

Brown, W.M., 1983. Evolution of mitochondrial DNA. In: M. Nei and R.K. Koehn (Editors), Evolution of Genes and Proteins. Sinauer, Sunderland, MA, pp. 62-88.

Dentry, W. and Lindsay, C.C., 1978. Vertebral variation in zebra-fish (Brachydiano rerio) related to the prefertilization temperature history of their parents. Can. J. Zool., 56: 280-283.

Drouin, J., 1980. Cloning of human mitochondrial DNA in Escherichia coli. J. Mol. Biol., 140: 15-34.

FAO, 1980. Report of the Ad Hoc Consultation on Aquaculture Research. FAO Fisheries Report 238, FIR/R238. FAO, Rome, 26 pp.

Ferris, S.D. and Berg, W.J., 1987. The utility of mitochondrial DNA in fish genetics and fishery management. In: N. Ryman and F. Utter (Editors), Population Genetics and Fishery Management. Univ. of Washington Press, Seattle, WA, pp. 277-299.

Gyllensten, U. and Wilson, A.C., 1987. Mitochondrial DNA of salmonids: Inter- and intraspecific variability detected with restriction enzymes. In: N. Ryman and F. Utter (Editors), Population Genetics and Fishery Management. Univ. of Washington Press, Seattle, WA, pp. 301-317.

Kornfield, I., 1984. Descriptive genetics of cichlid fishes. In: B.J. Turner (Editor), Evolutionary Genetics of Fishes. Plenum Press, New York, NY, pp. 590-616.

Kornfield, I., 1991. Genetics. In: M. Keenleyside (Editor), Cichlid Fishes: Behavior, Biology and Evolution. Chapman and Hall, London, pp. 103-128.

Kornfield, I. and Bogdanowicz, S.M., 1987. Differentiation of mitochondrial DNA in Atlantic herring. Fish. Bull., 85: 561-568.

Kornfield, I., Ritte, U., Richler, U. and Wahrman, J., 1979. Biochemical and cytological differentiation among cichlid fishes of the Sea of Galilee. Evolution, 33: 1-14.

Lansman, R.A., Shade, R.O., Shapiro, J.F. and Avise, J.C., 1981. The use of restriction endonucleases to measure mitochondrial DNA sequence relatedness in natural populations. III. Techniques and potential applications. J. Mol. Evol., 17: 214-226.

McAndrew, B.J. and Majumdar, K.C., 1983. Tilapia stock identification using electrophoretic markers. Aquaculture, 30: 249-261.

McAndrew, B.J. and Majumdar, K.C., 1984. Evolutionary relationships within three Tilapiine genera (Pisces: Cichlidae). Zool. J. Linn. Soc., 80: 421-435.

McKaye, K.R., Kocher, T., Reinthal, P., Harrison, R. and Kornfield, I., 1984. Genetic evidence for allopatric and sympatric differentiation among color morphs of a Lake Malawi cichlid fish. Evolution, 38: 215-219.

Maniatias, T., Fritsch, E.F. and Sambrook, J., 1982. Molecular Cloning - a Laboratory Manual. Cold Spring Harbor Laboratory, Cold Spring Harbor, NY, 545 pp. 
Moritz, C., Dowling, T.E. and Brown, W.M., 1987. Evolution of animal mitochondrial DNA: Relevance for population biology and systematics. Annu. Rev. Ecol. Syst., 18: 269-292.

Palva, T.K. and Palva, E.T., 1987. Restriction site polymorphism in mitochondrial DNA of rainbow trout, Salmo gairdneri, Richardson, stocks in Finland. Aquaculture, 67: 283-289.

Ryman, N., Lagercrantz, U., Andersson, L., Chakraborty, R. and Rosenberg, R., 1984. Lack of correspondence between genetic and morphological variability patterns in Atlantic herring (Clupea harengus). Heredity, 53: 687-704.

Sage, R.D. and Selander, R.K., 1975. Trophic radiation through polymorphism in cichlid fishes. Proc. Natl. Acad. Sci, U.S.A., 72: 4669-4673.

Sage, R.D., Loiselle, P.V., Basaibwaki, P. and Wilson, A.C., 1984. Molecular versus morphological change among cichlid fishes (Pisces: Cichlidae) of Lake Victoria. In: A.A. Echelle and l. Kornfield (Editors), Evolution in Fish Species Flocks. University of Maine, Orono Press, Orono, ME, pp. 185-202.

Seyoum, S., 1989. Stock identification and the evolutionary relationships of the tilapiine fishes of the genera Oreochromis. Sarotherodon and Tilapia (Pisces: Cichlidae) using allozyme analysis and restriction endonuclease analysis of mitochondrial DNA. Ph.D. Thesis, University of Waterloo, Waterloo, Ont., Canada, $336 \mathrm{pp}$.

Seyoum, S., 1990. Allozyme variation in subspecies of Oreochromis niloticus. Isozyme Bull., 23: 97.

Shaklee, J.B., 1983. The utilization of isozymes as gene markers in fisheries management and conservation. In: M.C. Rattazzi, J.G. Scandallos and G.S. Whitt (Editors), Isozymes: Current Topics in Biological and Medical Research, Vol. 11. Alan R. Liss, New York, NY, pp. 213-247.

Trewavas, E., 1983. Tilapiine Fishes of the Genera Oreochromis, Sarotherodon and Danakilia. British Museum of Natural History, London, 583 pp.

Utter, F., 1987. Protein electrophoresis and stock identification in fishes. In: H.E. Kumppf, R.N. Vaught, C.B. Grimes, A.G. Johnson and E.L. Nakamura (Editors), Proceedings of the Stock Identification Workshop, NOAA Technical Memorandum NMFS-SEFC-199. U.S. Department of Commerce, Washington, DC, pp. 63-104.

Welcomme, R.L., 1981. Register of International Transfers of Inland Fish Species. FAO Fisheries Technical Paper No. 213. FAO, Rome, 120 pp.

Wilson, A.C., Cann, R.L., Carr, S.M., George, M., Gyllensten, U.B., Helm-Bychowski, K.M., Higuchi. R.G., Palumbi, S.R., Prager, E.M., Sage, R.D. and Stoneking, M., 1985. Mitochondrial DNA and two perspectives on evolutionary genetics. Biol. J. Linn. Soc., 26: 375-400. 


\section{APPENDIX}

Restriction enzyme digestion patterns of Oreochromis niloticus subspecies. Capital letters denote enzyme-specific phenotypes. Cleavage fragments of identical size are homologous for a given enzyme. Asterisks denote two fragments with equal molecular size which were visualized as extra intense bands on autoradiographs

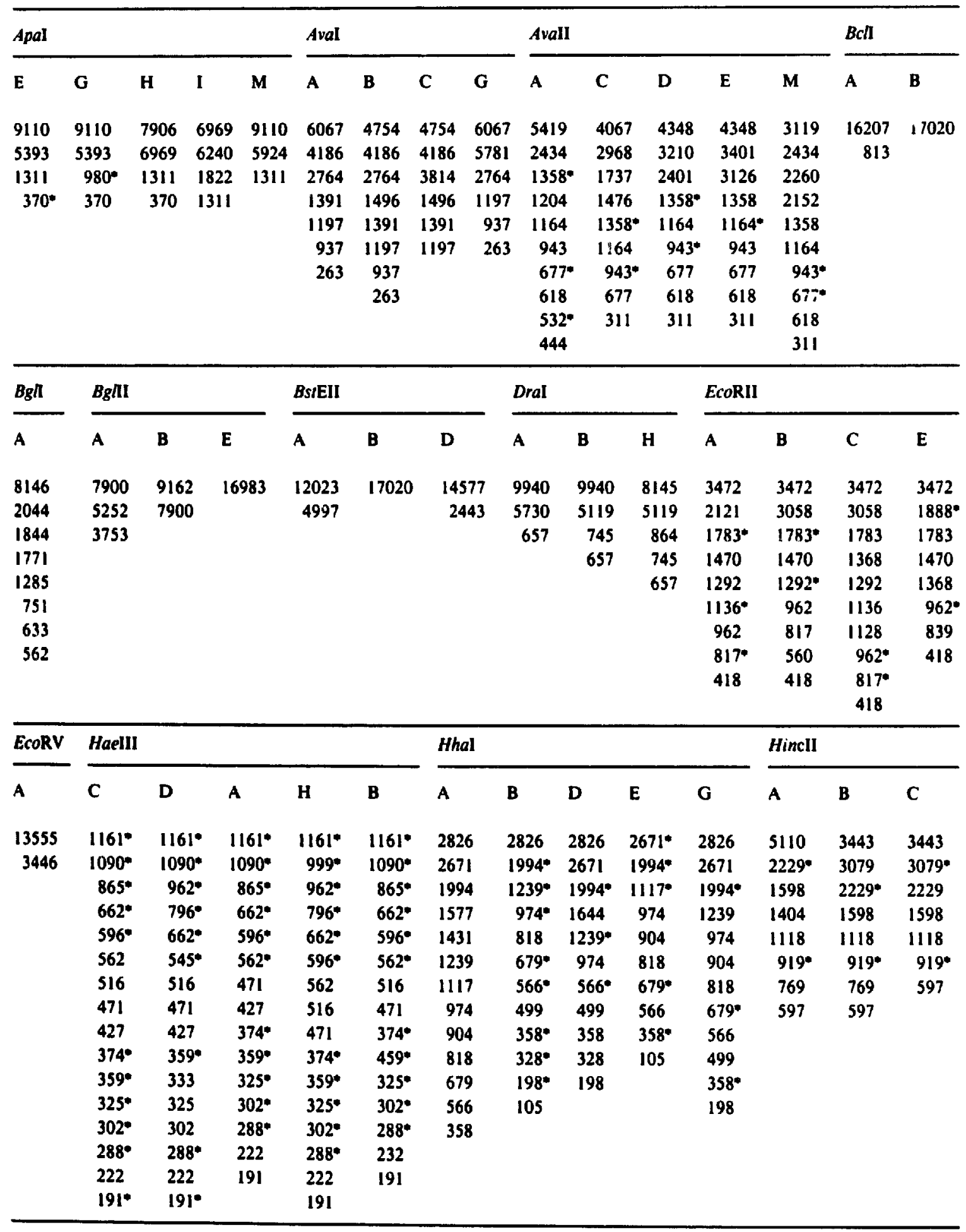


HindIII

\begin{tabular}{|c|c|c|c|}
\hline \multicolumn{2}{|c|}{ HindIII } & \multicolumn{2}{|l|}{ Hpal } \\
\hline$A$ & D & A & B \\
\hline 12600 & 12600 & 8688 & 8688 \\
\hline \multirow[t]{3}{*}{4385} & 4130 & 3321 & 6379 \\
\hline & 569 & 2645 & 2120 \\
\hline & & 2120 & \\
\hline
\end{tabular}

Hinfl
A

$\begin{array}{cccccccc}2572 & 3822 & 2572 & 2572 & 3807 & 1953^{*} & 217 \% & 1953^{*} \\ 1803^{*} & 1446^{*} & 1803^{*} & 1291 & 1803 & 1863 & 1863 & 1863 \\ 1229^{*} & 1229^{*} & 1229 & 1229 & 1229^{*} & 1568^{*} & 1324^{*} & 1324^{*} \\ 1047^{*} & 1090 & 1090 & 1090 & 1047 & 1324^{*} & 1157 & 1157 \\ 944^{*} & 1047^{*} & 1047 & 1047^{*} & 944^{*} & 1019 & 1019 & 1019^{*} \\ 798 & 632^{*} & 944 & 944^{*} & 798^{*} & 766^{*} & 766^{*} & 766^{*} \\ 593 & 593^{*} & 798 & 798^{*} & 477 & 567 & 712 & 567 \\ 477 & 446^{*} & 593^{*} & 593^{*} & 446 & 537 & 666^{*} & 537^{*} \\ 446 & 369^{*} & 536^{*} & 477^{*} & 429^{*} & 374 & 567 & 400^{*} \\ 369^{*} & 329^{*} & 477 & 461 & 369^{*} & 324 & 537 & 374 \\ 329^{*} & 303 & 446 & 446^{*} & 329^{*} & 302 & 477 & 324 \\ 270^{*} & 270 & 392 & 369^{*} & 270 & 256^{*} & 412^{*} & 302 \\ 187 & 235 & 369 & 329^{*} & 235 & 185 & 324^{*} & 256 \\ 149 & 187 & 345 & 270 & 187 & 154 & 302^{*} & 185 \\ 77 & 149 & 329^{*} & 187^{*} & 149^{*} & 88 & 256^{*} & 154 \\ & 77 & 270 & 145 & 77 & & 185 & 88 \\ & & 235 & 77 & & & 154 & \end{array}$

Ndel

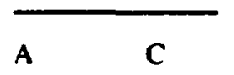

$17020 \quad 16288$

732

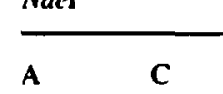

C

17020

$17020 \quad 15552$

1468
Psil

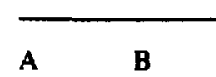

$7526 \quad 11706$

$5296 \quad 5296$
Pvull

A

$11496 \quad 13034$

1232* 1003* $1003^{*} 948^{*}$ 970

Mbol

Mspl

\begin{tabular}{lllll}
\hline A & B & D & E & F
\end{tabular}

B $\quad$ D $\quad$ E $\quad$ J

\section{$1953^{\circ} 1953^{*} \quad 1961$}

2838 1430* $3173^{*}$ $\begin{array}{lll}863 & 1863 & 1752\end{array}$

1324* $1324^{*} \quad 1478$

$1157^{*} \quad 1157 \quad 1430$

$1478^{*}$

$1138^{*} 1478^{*}$

$1430^{*} 1064^{*} \quad 1430$

$1064866^{*} 1138$

77

\begin{tabular}{lllllll}
\hline Mholl & & & & & \\
\hline A & B & C & D & E & H \\
& & & & & \\
$1974^{*}$ & 2250 & $1974^{*}$ & $1974^{*}$ & $1974^{*}$ & $1974^{*}$ \\
$1882^{*}$ & $1882^{*}$ & $1882^{*}$ & $1882^{*}$ & $1882^{*}$ & $1882^{*}$ \\
$1310^{*}$ & $1310^{*}$ & $1310^{*}$ & $1310^{*}$ & 1535 & $1310^{*}$ \\
1156 & 1156 & 1020 & $1156^{*}$ & $1310^{*}$ & 1156 \\
$1020^{*}$ & 1020 & 775 & 1020 & $1020^{*}$ & 1020 \\
$775^{*}$ & $775^{*}$ & $719^{*}$ & $775^{*}$ & $775^{*}$ & 775 \\
$572^{*}$ & 719 & $693^{*}$ & 719 & $385^{*}$ & $719^{*}$ \\
$416^{*}$ & 693 & $572^{*}$ & 572 & $332^{*}$ & 693 \\
332 & $572^{*}$ & 492 & 385 & & 572 \\
& $492^{*}$ & 416 & 324 & & 492 \\
& 416 & 332 & & & 416 \\
& $332^{*}$ & & & & 332
\end{tabular}

Narl

Rsal

\begin{tabular}{lllllllll}
\hline A & A & B & C & D & E & F & G \\
14739 & 1969 & 1969 & $1969^{*}$ & $1969^{*}$ & 2313 & 1969 & $1969^{*}$ \\
2335 & 1720 & 1825 & $1720^{*}$ & 1720 & 1969 & 1720 & 1720 \\
& 1585 & 1720 & 1538 & 1620 & 1720 & 1585 & 1585 \\
& 1492 & 1538 & 1128 & 1585 & 1533 & 1492 & 1492 \\
$1334^{*}$ & $1334^{*}$ & 1068 & 1334 & 1128 & 1334 & 1334 \\
1128 & $1128^{*}$ & $730^{*}$ & 1128 & 1068 & 1128 & 1128 \\
1068 & 1068 & 674 & 1068 & $730^{*}$ & 1068 & 1068 \\
& $730^{*}$ & 730 & $617^{*}$ & 730 & 674 & $900^{*}$ & 730 \\
& $601^{*}$ & 601 & 533 & $617^{*}$ & $617^{*}$ & $730^{*}$ & 617 \\
482 & 482 & 482 & 601 & 482 & $601^{*}$ & 600 \\
& 439 & 439 & 439 & 482 & 439 & 439 & 482 \\
400 & 400 & 400 & 439 & 400 & 425 & 439 \\
& $336^{*}$ & 336 & 336 & 336 & 336 & $336^{*}$ & 425 \\
308 & 308 & & 308 & 308 & 308 & 336 \\
& 256 & 256 & & 256 & 256 & 256 & 308 \\
202 & 202 & & 159 & 202 & 202 & 256 \\
159 & 159 & & & 159 & 159 & 202 \\
& & & & & & & 159
\end{tabular}


APPENDIX (continued)

\begin{tabular}{|c|c|c|c|c|c|c|c|c|c|c|c|c|c|}
\hline \multicolumn{4}{|l|}{ Ncil } & \multicolumn{3}{|l|}{ SphI } & \multicolumn{3}{|l|}{ Styl } & \multicolumn{4}{|l|}{ Taql } \\
\hline A & B & $\mathbf{E}$ & $x$ & $\mathbf{A}$ & $\mathbf{B}$ & $\mathbf{E}$ & A & D & $\mathbf{E}$ & $\mathbf{A}$ & B & C & $\mathbf{F}$ \\
\hline 6503 & 6503 & 7504 & 6503 & 16989 & 9175 & 10396 & 7308 & 7308 & 7688 & $1349^{\circ}$ & $1349^{*}$ & 1349 & $1349^{\circ}$ \\
\hline 2584 & 2584 & 2584 & 2584 & & 7814 & 6593 & 1690 & 1690 & 1690 & 1285 & 1285 & 1285 & $1285^{\circ}$ \\
\hline 1793 & 2030 & 1793 & 2466 & & & & 1543 & $1543^{\circ}$ & 1543 & 1176 & 1176 & $1176^{*}$ & 1071 \\
\hline $1528^{*}$ & 1793 & 1528 & 1793 & & & & $895^{*}$ & 999 & 895 & 1071 & 1071 & 1071 & $96 \mathrm{l}^{*}$ \\
\hline 798 & 1528 & 798 & 1528 & & & & 825 & 895 & 825 & 991 & 991 & 991 & $814^{*}$ \\
\hline 731 & 731 & 505 & 798 & & & & $768^{*}$ & 825 & 768 & $961^{*}$ & $961^{*}$ & $961^{*}$ & $780^{*}$ \\
\hline $437^{*}$ & 658 & 437 & 731 & & & & 642 & 768 & 535 & 814 & 814 & 814 & $594^{*}$ \\
\hline 339 & 437 & 339 & 437 & & & & 413 & 642 & $517^{*}$ & 780 & 780 & 780 & $546^{\circ}$ \\
\hline 333 & 339 & $333^{*}$ & 291 & & & & 356 & 413 & $472^{*}$ & $621^{\circ}$ & 621 & 628 & 448 \\
\hline \multirow[t]{2}{*}{239} & 333 & 325 & & & & & $288^{*}$ & 356 & 413 & $546^{\circ}$ & 594 & $621^{*}$ & 370 \\
\hline & 239 & 239 & & & & & 226 & 288 & 356 & $370^{*}$ & 546 & 546 & 345 \\
\hline \multirow{2}{*}{\multicolumn{2}{|c|}{ Thal }} & \multirow{2}{*}{\multicolumn{2}{|c|}{ Xbal }} & & & & 203 & & 226 & 345 & 525 & 525 & $328^{*}$ \\
\hline & & & & \multicolumn{2}{|l|}{$X m n I$} & & & & 203 & $328^{*}$ & 448 & 448 & 293 \\
\hline \multirow[t]{2}{*}{$\mathbf{A}$} & B & $\mathbf{A}$ & B & $\mathbf{A}$ & C & & & & & 261 & $345^{*}$ & $345^{*}$ & $261^{*}$ \\
\hline & & & & & & & & & & $246^{*}$ & 328 & 311 & 209 \\
\hline 4891 & 4185 & 9980 & 7767 & 6545 & 5624 & & & & & $237^{*}$ & $293^{*}$ & 293 & 191 \\
\hline 4185 & 2991 & 5963 & 5963 & 5624 & 4876 & & & & & 209* & $261^{*}$ & $261^{*}$ & 166 \\
\hline 2991 & 2652 & 874 & 2196 & 2020 & 2479 & & & & & & 246 & 246 & \\
\hline 2324 & 2425 & & 874 & 1084 & 1459 & & & & & & $191^{*}$ & 209 & \\
\hline 1165 & 1381 & & & $797^{*}$ & $797^{*}$ & & & & & & 166 & $191^{*}$ & \\
\hline 555 & 1165 & & & & 642 & & & & & & & 166 & \\
\hline \multirow[t]{3}{*}{$516^{*}$} & 766 & & & & & & & & & & & & \\
\hline & 555 & & & & & & & & & & & & \\
\hline & $516^{*}$ & & & & & & & & & & & & \\
\hline
\end{tabular}

For digestion patterns exhibiting one to three restriction fragments, the size of the largest fragment was obtained by subtraction from the estimated molecular size of the mitochondrial DNA. 